\title{
ARTIKELEN
}

\section{Arbeidskosten en productiviteit van oudere werknemers}

\section{De visie van Nederlandse werkgevers in Europees perspectief ${ }^{*}$}

\author{
Wieteke Conen, Kène Henkens \& Joop Schippers ${ }^{* *}$
}

Percepties van arbeidskosten en productiviteit spelen een belangrijke rol voor de wijze waarop werkgevers met werknemers omgaan. In dit artikel wordt onderzocht welke consequenties een vergrijzend werknemersbestand volgens werkgevers zal hebben op arbeidskosten en productiviteit, en welke maatregelen werkgevers toepassen en overwegen om de arbeidskosten te verlagen, dan wel de arbeidsproductiviteit te verhogen. Analyses worden gedaan op basis van een survey, gehouden onder 5.822 werkgevers in Denemarken, Duitsland, Frankrijk, Italië, Nederland, Polen, het Verenigd Koninkrijk en Zweden. Uit de resultaten blijkt dat een aanzienlijk deel van de werkgevers een ouder wordend personeelsbestand associeert met een groter wordend gat tussen arbeidskosten en productiviteit; dit is vooral een issue in Nederland. Werkgevers die een groter gat tussen kosten en productiviteit verwachten, blijken niet vaker maatregelen te nemen om dit gat 'te dichten' - zoals opleiding voor oudere werknemers en demotie maar blijken wél vaker vervroegd pensioen of accommoderende maatregelen toe te passen. Wel overwegen werkgevers die een groter gat verwachten vaker maatregelen als demotie. We concluderen dat Europese werkgevers vooralsnog weinig maatregelen lijken te nemen om een van de grootste verwachte negatieve consequenties van een vergrijzend personeelsbestand - een groter wordend gat tussen arbeidskosten en productiviteit - het hoofd te bieden.

\section{Inleiding}

De vergrijzing van de samenleving en de beroepsbevolking hebben grote consequenties voor de financiering van welvaartsstaten en zullen de samenstelling en omvang van het arbeidsaanbod grondig veranderen. Hoewel op de korte termijn

* Dit onderzoek werd gefinancierd binnen het Zevende Kaderprogramma (FP7/2007-2013) van de EU onder subsidie FP7-216289 (ASPA).

** Wieteke Conen is werkzaam bij de Universiteit Utrecht, Faculteit Recht, Economie, Bestuur en Organisatie. E-mail: W.S.Conen@uu.nl. Kène Henkens is werkzaam bij het Nederlands Interdisciplinair Demografisch Instituut (NIDI), Den Haag, de Universiteit van Amsterdam, Faculteit der Maatschappij- en Gedragswetenschappen en het Universitair Medisch Centrum Groningen, afdeling Gezondheidswetenschappen. Joop Schippers is werkzaam bij de Universiteit Utrecht, Faculteit Recht, Economie, Bestuur en Organisatie. 


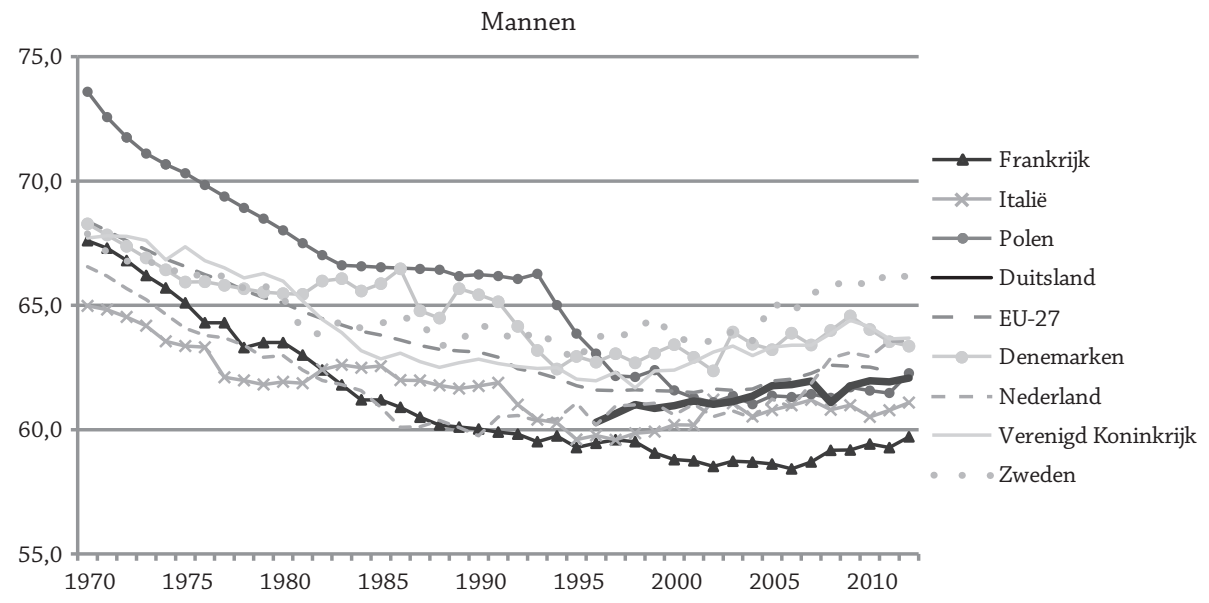

Figur 1 Gemiddelde effectieve pensioenleeftijd (bron: OECD, 2015)

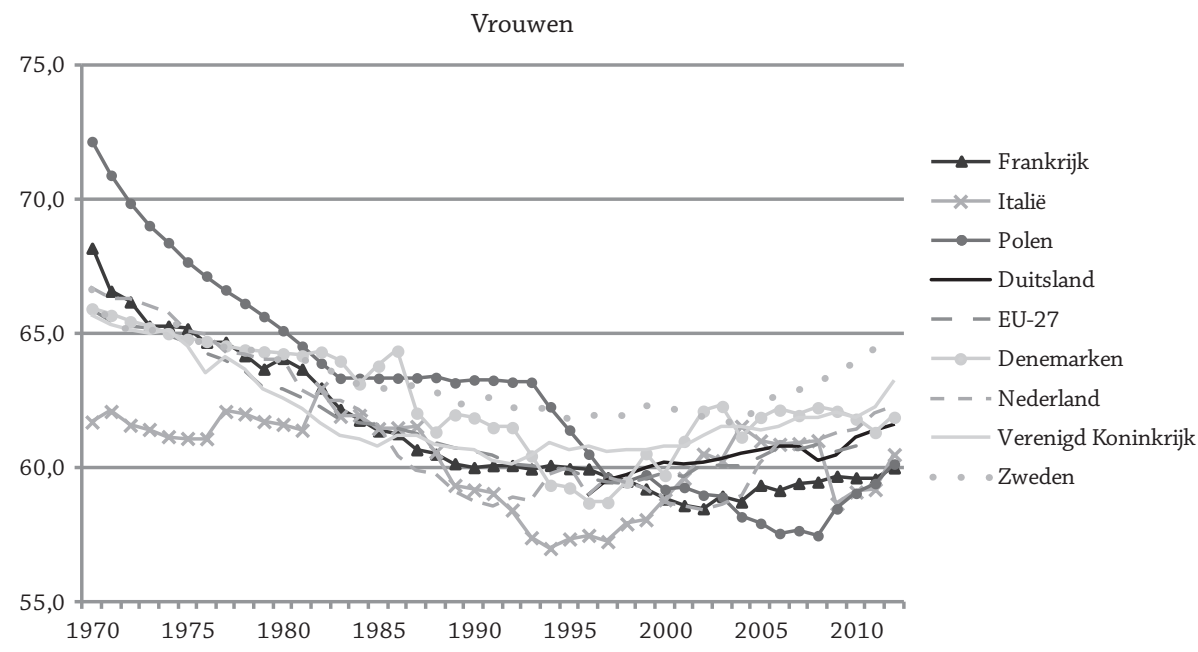

Figur 2 Gemiddelde effectieve pensioenleeftijd (bron: OECD, 2015)

de huidige economische crisis zorgt voor een ruimer arbeidsaanbod, wordt voor veel Europese regio's op de langere termijn een afname verwacht van het arbeidsaanbod. Bovendien zal vergrijzing zorgen voor stijgende kosten van welvaartsstaten, met name door de toenemende kosten van zorg en pensioenen (Europese Commissie, 2006). In veel landen wordt daarom overheidsbeleid gevoerd dat als doel heeft om participatiegraden van oudere werknemers te verhogen en arbeidslevens te verlengen.

Over het afgelopen decennium bezien zijn oudere werknemers langzaamaan meer en langer gaan werken (Eurostat, 2015). Ondanks deze opwaartse trend geldt voor de meeste landen nog steeds dat de effectieve pensioenleeftijd vaak ruim 
onder de wettelijke pensioenleeftijd ligt (zie figuur 1 en 2). De arbeidsparticipatie daalt vaak aanzienlijk bij werknemers tussen de 55-59 jaar en daalt sterk na het 60ste levensjaar (Eurostat, 2015). Met andere woorden: in de meeste landen is vervroegd pensioen nog steeds eerder regel dan uitzondering. Een land als Zweden vormt hierop een uitzondering en doet het relatief goed op het punt van het behouden van oudere werknemers voor de arbeidsmarkt.

Hoewel vervroegd pensioen dan de regel lijkt te zijn, zijn er grote verschillen in de arbeidsparticipatie van ouderen tussen Europese landen. Dit wordt door velerlei aspecten bepaald, waaronder institutionele arrangementen die zowel vraag naar als aanbod van oudere werknemers beïnvloeden, alsmede de houdingen en het gedrag van werkgevers en werknemers ten aanzien van langer doorwerken. De vraag die centraal staat in dit artikel, is hoe werkgevers aankijken tegen vergrijzing en de consequenties van een verouderende beroepsbevolking. Dit is een perspectief dat vaak onderbelicht blijft ten opzichte van de vraag wat de overheid en oudere werknemers willen en doen.

Toch spelen werkgevers een sleutelrol in de arbeidsmobiliteit van oudere werknemers, hun mogelijkheden om banen te behouden en het moment van de definitieve transitie van werk naar pensioen. Belemmeringen voor werkgevers om oudere werknemers aan te nemen of te behouden worden vaak toegeschreven aan een toenemend loon-productiviteitsgat, dat wil zeggen dat arbeidskosten van werknemers sterker toenemen dan hun productiviteit naarmate men ouder wordt (Gelderblom, 2005; OECD, 2006). Sommige studies komen tot de conclusie dat het loon-productiviteitsgat groter wordt naarmate men ouder wordt (Kotlikoff \& Gokhale, 1992; Crépon et al., 2002; Hellerstein \& Neumark, 2004; Ilmakunnas \& Maliranta, 2005), terwijl andere studies weinig bewijs vinden voor een leeftijdgebonden loon-productiviteitsgat (Aubert \& Crépon, 2007; Van Ours \& Stoeldraijer, 2010).

Dit artikel draagt bij aan de bestaande literatuur door niet zozeer feitelijke veranderingen in het loon-productiviteitsgat te analyseren, maar door te onderzoeken wat de gepercipieerde consequenties van een vergrijzend personeelsbestand zijn in termen van arbeidskosten en productiviteit. Het gaat dus om wat werkgevers vinden, los van de vraag of wat zij vinden ook daadwerkelijk klopt. Vermoedelijk spelen die verwachtingen een belangrijke rol in het uiteindelijke gedrag van werkgevers. Daarnaast wordt niet alleen dieper ingegaan op welk beleid werkgevers nu al hebben ten aanzien van oudere werknemers, maar ook welke maatregelen werkgevers overwegen. Ten slotte is dit artikel een van de eerste die de verwachtingen van werkgevers vanuit een crossnationaal perspectief beziet. Deze crossnationale dimensie geeft meer informatie over de vraag in hoeverre percepties van Nederlandse werkgevers overeenkomen met dan wel verschillen van die van werkgevers in andere landen.

In dit artikel willen we de volgende twee hoofdvragen beantwoorden:

- Welke consequenties heeft een vergrijzend werknemersbestand volgens werkgevers in termen van arbeidskosten en productiviteit? 
- Welke maatregelen nemen en overwegen werkgevers ten aanzien van hun oudere werknemers om arbeidskosten te verlagen, dan wel arbeidsproductiviteit te verhogen?

Het artikel maakt gebruik van unieke data die zijn verzameld via een survey onder Europese werkgevers. De vragenlijsten zijn in 2009 toegestuurd aan arbeidsorganisaties in Denemarken, Duitsland, Frankrijk, Italië, Nederland, Polen, het Verenigd Koninkrijk en Zweden. Alvorens stil te staan bij de uitkomsten van het empirisch onderzoek onder werkgevers, besteden we kort aandacht aan enkele inzichten uit met name de economische en sociaalpsychologische literatuur.

\section{Theoretisch kader}

\section{Leeftijd, productiviteit en arbeidskosten}

De discussie over de relatie tussen leeftijd, arbeidsproductiviteit en arbeidskosten start vaak bij de theorie van het menselijk kapitaal (Becker, 1962; zie voor een overzicht Polachek \& Siebert, 1993). Volgens deze theorie bevorderen investeringen in menselijk kapitaal de productiviteit, en productiviteit hangt in positieve zin samen met de beloning van werknemers. De meeste mensen leggen in het eerste deel van hun leven een basisvoorraad menselijk kapitaal aan in de vorm van kennis en vaardigheden die zij zich gedurende hun opleiding eigen maken. Na het betreden van de arbeidsmarkt wordt additioneel menselijk kapitaal verworven in de vorm van ervaring en training. Menselijk kapitaal, en daarmee ook het productieve vermogen van een werknemer, is echter ook aan depreciatie onderhevig, bijvoorbeeld omdat kennis van oudere technologieën overbodig raakt of wanneer fysieke vaardigheden 'slijten'.

Skirbekk (2008) geeft een overzicht van de manier waarop leeftijd verscheidene fysieke en cognitieve vaardigheden beïnvloedt, en hoe zich dit vertaalt in veranderingen in productief vermogen. Voor fysieke vaardigheden geldt dat het biologisch proces van interne depreciatie onomkeerbaar is, hoewel inter-individuele verschillen aanzienlijk zijn. Gemiddeld genomen zijn ouderen in fysiek opzicht de mindere van jongeren. Rond de 30 jaar begint het fysieke vermogen af te nemen, maar omdat dit een zeer langzaam proces is en de meeste organen overcapaciteit hebben, worden problemen vaak pas vanaf een jaar of 60 gesignaleerd. Vanaf 45 jaar valt veel mensen op dat hun fysieke conditie achteruitgaat. Oudere werknemers hebben over het algemeen een langere herstelperiode (Hidding et al., 2004; Nauta et al., 2004). De capaciteiten die het cognitief functioneren bepalen, worden vaak onderverdeeld in 'fluid cognitive skills' en 'crystallized cognitive skills' (Horn \& Catell, 1967; Baltes et al., 1999). 'Fluid cognitive skills' refereren aan het proces van het verzamelen van informatie, snelheid en geheugen, waarvan de kwaliteit genetisch bepaald is en een hoge inter-individuele variatie kent; deze vaardigheden nemen af naarmate men ouder wordt. 'Crystallized cognitive skills' refereren aan kennis en ervaring die is opgeslagen in een individu en die mensen in staat stelt complexere situaties in te schatten en op te lossen; deze vaardigheden nemen toe naarmate men ouder wordt. Daarnaast compenseren ouderen 
lagere 'fluid abilities' vaak door adaptatie-strategieën toe te passen (Baltes et al., 1999).

Depreciatie van menselijk kapitaal leidt tot een afnemende productiviteit en zou - vanuit de theorie bezien - resulteren in een teruglopende beloning. Mede omdat die afnemende beloning feitelijk zelden werd waargenomen, ontstonden aan het eind van de jaren zeventig van de vorige eeuw twijfels omtrent de relatie tussen leeftijd, arbeidskosten en productiviteit als beschreven in de theorie van het menselijk kapitaal (Hutchens, 1989). Lazear (1979) was een van de eersten die zich boog over vragen als: Waarom bestaan er banen waarin lonen toenemen naarmate men ouder wordt - ongeacht de productiviteitstoename? En waarom bestaat er een wettelijk verplichte pensioenleeftijd? Lazears contracttheorie met uitgestelde betaling laat zien hoe werkgevers in wezen impliciete contracten met hun werknemers sluiten aangaande de relatie tussen productiviteit en inkomen gedurende de levensloop: de beloning is lager dan productiviteit in de eerste fase van de carrière van een werknemer en hoger dan productiviteit gedurende de tweede fase. Dergelijke contracten functioneren als prikkels voor werknemers om voldoende inzet te leveren in hun werk om dat hogere loon te bemachtigen aan het eind van de contractperiode. Een werknemer die de kantjes er vanaf loopt, loopt het risico te worden ontslagen voordat de 'premie' binnen is. Andere contracttheorieën houden bijvoorbeeld rekening met de onzekerheid over de productiviteit van nieuw geworven werknemers (Harris \& Holmstrom, 1982) - vandaar dat ze een relatief laag loon bieden aan nieuwe werknemers, of met de betrouwbaarheid van werknemers in de zin dat jongere werknemers vaker de organisatie verlaten (Grossman, 1977). Wat deze contracttheorieën met elkaar gemeen hebben, is dat ze een contante-waarde-relatie tussen beloning en productiviteit impliceren, waarbij jongeren een loon krijgen dat lager is dan hun productiviteit, en ouderen een loon hoger dan hun productiviteit.

In organisaties waar beloning in lijn is met de theorie van het menselijk kapitaal, zullen werkgevers in principe geen loon-productiviteitsgat ervaren bij een ouder wordend personeelsbestand. In organisaties waar contracten gebaseerd zijn op uitgestelde beloning, is dit wel het geval. Het vooruitzicht van langer doorwerken impliceert hoe dan ook een langere contractperiode en dus zou de productiviteit een langere periode op peil moeten worden gehouden.

In wezen kunnen werkgevers drie dingen doen om het loon-productiviteitsgat tijdens het laatste deel van de levensloop zoveel mogelijk te beperken: (1) verhogen van productiviteit, (2) het verlagen van arbeidskosten en (3) het in balans brengen van arbeidskosten en productiviteit. Werkgevers kunnen bijvoorbeeld door middel van trainingen voor oudere werknemers het menselijk kapitaal op peil houden en een eventuele terugloop in productiviteit tegengaan. Om arbeidskosten te verlagen is een mogelijke oplossing het laten gaan c.q. actief afscheid nemen van relatief duur personeel. In die zin kunnen regelingen voor vervroegde uittreding worden gezien als een manier om arbeidskosten te verlagen. Demotie oftewel: teruggang in functie én salaris - is een voorbeeld van een maatregel om balans terug te brengen tussen beloning en productiviteit. Training en demotie wanneer weldoordacht toegepast - worden vaak genoemd als mogelijke oplossingen om negatieve consequenties van een vergrijzende beroepsbevolking tegen te 
gaan (Hall \& Isabella, 1985; Europese Commissie, 2006; Van Dalen \& Henkens, 2014). Wanneer werkgevers geen mogelijkheden zien om het gat te verkleinen, kunnen zij ook kiezen voor (4) accommoderende maatregelen om de huidige productiviteit van een werknemer zoveel mogelijk stabiel te houden. In deze categorie kan worden gedacht aan maatregelen zoals taakverlichting voor oudere werknemers, extra verlofmogelijkheden voor oudere werknemers of werktijdvermindering voorafgaand aan pensioen. Accommoderende maatregelen maken werknemers in principe per saldo 'duurder', maar kunnen bijvoorbeeld de kans op overbelasting verkleinen, alsmede de productieve inzet in de gewerkte uren vergroten.

\section{Percepties}

Beeldvorming of percepties vormen een manier om informatie zo effectief mogelijk te verwerken en te ordenen, hetgeen gebeurt door middel van categorisering en stereotypering. Categorisering houdt in dat wanneer men informatie waarneemt, men deze gegevens in categorieën 'opbergt' (in hokjes plaatst) die corresponderen met bepaalde vindplaatsen in het geheugen (zie voor een uitgebreide uitleg Brewer et al., 1981). Het denken in categorieën is vooral 'cognitively economical' (Macrae \& Bodenhausen, 2001, p. 241). Het creëren van sociale categorieën is gebaseerd op aanwezige eigenschappen van een persoon, zoals leeftijd, geslacht, ras, etniciteit en sociale status. Stereotypering kan worden omschreven als: 'Beliefs about the characteristics, attributes, and behaviours of members of certain groups (...) and beliefs about how and why these attributes go together' (Hilton \& Von Hippel, 1996, p. 240).

In bovenstaande definitie wordt gesproken over groepen mensen. Leden van een groep neigen ertoe om de overeenkomsten tussen de leden binnen een groep te overschatten en de verschillen te onderschatten (Linville et al., 1989; Verkuyten \& Nekuee, 1999), zodat de verschillen tussen groepen als veel groter worden ervaren dan ze in werkelijkheid zijn. Categorisatie en stereotypering leiden ertoe dat mensen meer geneigd zijn om positieve eigenschapen toe te schrijven aan leden van de eigen groep (in-group bias) en meer negatieve eigenschappen toe te schrijven aan leden van andere groepen (out-group bias) waartoe men niet behoort (Tajfel \& Turner, 1979; Lalonde \& Gardner, 1989). Stereotypen hoeven in eerste instantie niet altijd negatief te zijn, maar stereotypen over 'out-group'-leden hebben vaker een meer negatieve connotatie dan stereotypen over 'in-group'-leden (Tajfel \& Turner, 1979; Hilton \& Von Hippel, 1996). De sociale psychologie beschouwt het proces van categoriseren van mensen in sociale groepen en hen stereotyperen op basis daarvan, als een centraal en fundamenteel onderdeel van het cognitief proces. Hoewel beeldvorming een proces is dat niet gemakkelijk veranderd kan worden, omdat categorieën zodanig verankerd zijn in het cognitieve systeem dat zij als vanzelfsprekend geactiveerd worden (Devine, 1989; Hilton \& Von Hippel, 1996), kan men door betere informatie en het frequenter contact hebben met groepen mensen, zoals ouderen, toch een genuanceerder beeld creëren over bepaalde groepen (Snyder, 1981; Lee \& Clemons, 1985). 


\section{Methode}

\section{Enquête onder werkgevers}

Voor het onderzoek is een vragenlijst geconstrueerd die is afgenomen onder werkgevers in Denemarken, Duitsland, Frankrijk, Italië, Nederland, Polen, het Verenigd Koninkrijk en Zweden (zie ook Conen, 2013). Participerende onderzoeksinstituten binnen het ASPA-project verzorgden de datacollectie. 'ASPA' is een acroniem voor 'Activating Senior Potential in Ageing Europe'. Dit is een onderzoeksproject dat is gefinancierd binnen het EU Zevende Kaderprogramma onder het thema Socio-economische Wetenschappen en Geesteswetenschappen. De dataverzameling vond plaats tussen maart en november 2009. In totaal zijn 5.822 vragenlijsten afgenomen, waarvan 609 in Denemarken, 500 in Frankrijk, 892 in Duitsland, 770 in Italië, 1.077 in Nederland, 1.037 in Polen, 412 in het Verenigd Koninkrijk en 525 in Zweden (zie bijlage 1). De totale respons bedraagt $23 \%$ en varieert van $7 \%$ tot $53 \%$ in de verschillende landen. Dit is lager dan de gemiddelde respons bij onderzoek onder individuen, maar in overeenstemming met het responspercentage dat veelal bereikt wordt bij onderzoek onder bedrijven. In Europa en de Verenigde Staten worden doorgaans responspercentages bereikt tot 20 à 30\% (zie Brewster et al., 1994; Kalleberg et al., 1996). De vragenlijsten waren in alle landen identiek. De enquête werd vertaald vanuit het Engels naar de taal in het desbetreffende land. Deze nationale vragenlijsten werden voorafgaand aan het veldwerk door de coördinator gecheckt op internationale vergelijkbaarheid.

De vragenlijsten waren gericht aan leden van directie of bestuur, eigenaren en hoofden P\&O. De gebruikte interviewtechniek verschilde tussen landen, afhankelijk van wat geacht werd de beste manier te zijn om organisaties te benaderen in het betreffende land. Denemarken gebruikte cumputer-assisted web interviewing; Duitsland, Nederland en Zweden gebruikte schriftelijke vragenlijsten; en Frankrijk, Italië, Polen en het Verenigd Koninkrijk maakte gebruik van compter-assisted telephonic interviewing.

In alle landen werd een gestratificeerde steekproef getrokken naar sector en grootte van de vestigingen. In de analyses op nationaal niveau hebben we de data achteraf gewogen om te corrigeren voor dit steekproefdesign; dit om te zorgen dat de observaties representatief zijn voor de nationale populatie van werkgevers. Wegingen zijn geconstrueerd op basis van de populaties van vestigingen volgens nationale bureaus voor statistiek en corrigeren voor sector en omvang van vestigingen. In de analyses op gepoold niveau hebben we de data voor alle acht landen - inclusief de nationale weegfactoren - samengevoegd en een nieuwe weegfactor aangemaakt die bovendien de netto steekproefomvang in de verschillende landen meeweegt. Anders zouden Nederlandse en Poolse werkgevers $(N>1000)$ de resultaten sterker beïnvloeden dan Franse en Zweedse werkgevers $(\mathrm{N} \approx 500)$.

\section{Operationalisering}

De gevolgen van vergrijzing voor de organisatie zijn geoperationaliseerd door respondenten de vraag voor te leggen: Wat zijn volgens u de consequenties voor uw organisatie als de gemiddelde leeftijd van uw personeel toeneemt met 5 jaar? 
Consequenties voor de organisatie die men werd gevraagd te beoordelen, betroffen onder andere arbeidskosten, kennisniveau en arbeidsproductiviteit. De respondenten konden aangeven of ze een (sterke) afname dan wel een (sterke) toename verwachtten (antwoordcategorieën: 1 = sterke afname, 2 = afname, 3 = blijft hetzelfde, 4 = toename, 5 = sterke toename). Op basis van de verwachtingen rond arbeidskosten (schaal 1-5) minus arbeidsproductiviteit (schaal 1-5) hebben we een schaal voor het verwachte arbeidskosten-productiviteitsgat geconstrueerd (schaal -4 tot 4 ).

In de vragenlijst is daarnaast een reeks maatregelen voorgelegd die deel kunnen uitmaken van een leeftijdsbewust personeelsbeleid. Deze reeks is gebaseerd op eerder onderzoek naar dergelijk beleid (o.m. SZW, 1991; Remery et al., 2003). Voorbeelden van maatregelen zijn een opleidingsplan voor oudere werknemers, taakverlichting voor oudere werknemers, teruggang in functie en salaris (demotie), vervroegd pensioen. Aan respondenten werd gevraagd per maatregel aan te geven of deze momenteel werd toegepast of dat wordt overwogen om deze maatregel toe te passen.

\section{Resultaten}

\section{Leeftijd, productiviteit en arbeidskosten}

Wat verwachten werkgevers op het gebied van kennis, productiviteit en arbeidskosten als de gemiddelde leeftijd in de organisatie toeneemt? Tabel 1 geeft aan hoeveel procent van de werkgevers in het betreffende land een '(sterke) toename' dan wel een '(sterke) afname' verwacht. Uit de resultaten blijkt dat wat productiviteit betreft in alle landen een meerderheid van de werkgevers aangeeft dat productiviteit niet beïnvloed wordt door veroudering van het personeelsbestand. Desondanks is er ook een substantiële minderheid (28\%) van werkgevers die verwacht dat productiviteit (sterk) zal afnemen; dit percentage is het hoogst in Zweden, Duitsland en Nederland, waar ruim een derde deel van de werkgevers een productiviteitsafname verwacht, en het laagst in het Verenigd Koninkrijk, waar $15 \%$ verwacht dat de productiviteit zal dalen. Aan de andere kant verwacht $10 \%$ van de werkgevers een productiviteitstoename.

Het tweede deel van de tabel gaat over verwachtingen van werkgevers betreffende het kennisniveau: $42 \%$ van de werkgevers verwacht een (sterke) toename van het kennisniveau en $9 \%$ verwacht een afname. Wanneer de meningen over productiviteit en kennisniveau gecombineerd worden, dan valt op dat vanuit het gezichtspunt van werkgevers een toename van het kennisniveau zich kennelijk niet vertaalt in hogere productiviteit. Dit kan betekenen dat werkgevers die een toename van het kennisniveau verwachten bijvoorbeeld tevens verwachten dat andere dimensies van productiviteit - zoals fysieke en mentale belastbaarheid, flexibiliteit of andere vaardigheden - zullen afnemen of dat werkgevers productiviteit vooral associëren met andere dimensies van productiviteit dan het kennisniveau van werknemers. 
Tabel $1 \quad$ Verwachte consequenties van een verouderend personeelsstructuur voor de eigen organisatie, in procenten*

\begin{tabular}{|c|c|c|c|c|c|c|c|c|c|}
\hline Consequenties & Totaal & DK & DE & FR & IT & NL & PL & VK & SE \\
\hline \multicolumn{10}{|l|}{$\begin{array}{l}\text { Arbeidsproductivi- } \\
\text { teit }\end{array}$} \\
\hline (sterke) toename & 10 & 10 & 10 & 7 & 14 & 8 & 10 & 11 & 8 \\
\hline hetzelfde & 62 & 71 & 54 & 64 & 62 & 58 & 61 & 74 & 55 \\
\hline (sterke) afname & 28 & 19 & 36 & 28 & 25 & 34 & 29 & 15 & 37 \\
\hline \multicolumn{10}{|l|}{ Kennisniveau } \\
\hline (sterke) toename & 42 & 47 & 46 & 53 & 38 & 45 & 26 & 42 & 46 \\
\hline hetzelfde & 49 & 44 & 43 & 42 & 52 & 49 & 65 & 52 & 42 \\
\hline (sterke) afname & 9 & 9 & 11 & 5 & 10 & 7 & 9 & 6 & 12 \\
\hline \multicolumn{10}{|l|}{ Arbeidskosten } \\
\hline (sterke) toename & 44 & 33 & 48 & 51 & 49 & 75 & 16 & 34 & 44 \\
\hline hetzelfde & 52 & 61 & 51 & 43 & 48 & 24 & 74 & 62 & 50 \\
\hline (sterke) afname & 4 & 6 & I & 6 & 3 & 1 & 10 & 3 & 6 \\
\hline
\end{tabular}

Bron: ASPA werkgeversonderzoek, 2009

$* \mathrm{DK}=$ Denemarken, $\mathrm{DE}=$ Duitsland, FR $=$ Frankrijk, IT = Italië, NL = Nederland, PL $=$ Polen, $\mathrm{VK}=$ Verenigd Koninkrijk, SE = Zweden

Het derde deel van de tabel laat verwachtingen van werkgevers omtrent ontwikkelingen in arbeidskosten zien. Voor de gepoolde data geldt dat ongeveer de helft van de werkgevers een toename in arbeidskosten verwacht. We zien hier echter grote verschillen tussen landen. In Polen, Denemarken en het Verenigd Koninkrijk verwacht tot ongeveer een derde van de werkgevers dat arbeidskosten zullen toenemen. In Zweden, Duitsland, Italië en Frankrijk verwacht ongeveer de helft dat arbeidskosten zullen toenemen. Nederlandse werkgevers bevinden zich aan het andere eind van het spectrum: hier denkt $75 \%$ van de werkgevers dat arbeidskosten zullen toenemen door veroudering van het personeelsbestand. Maar weinig werkgevers denken dat arbeidskosten zullen afnemen (4\%).

Contracttheorieën met uitgestelde betaling voeren aan dat het niet zozeer een teruglopende productiviteit hoeft te zijn waardoor werkgevers langer doorwerken niet toejuichen, maar dat de vormgeving van het contract ervoor zorgt dat werknemers meer betaald krijgen dan ze 'waard' zijn op hogere leeftijd, ook wanneer de productiviteit gelijk blijft. Tabel 1 lijkt steun te bieden aan deze notie. De combinatie van verwachtingen over arbeidskosten en productiviteit laten zich vertalen in verwachtingen omtrent het arbeidskosten-productiviteitsgat door veroudering van personeel. Als een werkgever bijvoorbeeld een toename in arbeidskosten verwacht en een afname in productiviteit, dan duidt dit op een toename van het arbeidskosten-productiviteitsgat. Hetzelfde geldt voor een situatie waarin de productiviteit gelijk blijft, maar de arbeidskosten toenemen. Figuur 3 toont de resultaten van deze berekeningen.

In het algemeen geldt dat ongeveer de helft van de werkgevers verwacht dat het loon-productiviteitsgat zal toenemen met een verouderend personeelsbestand 


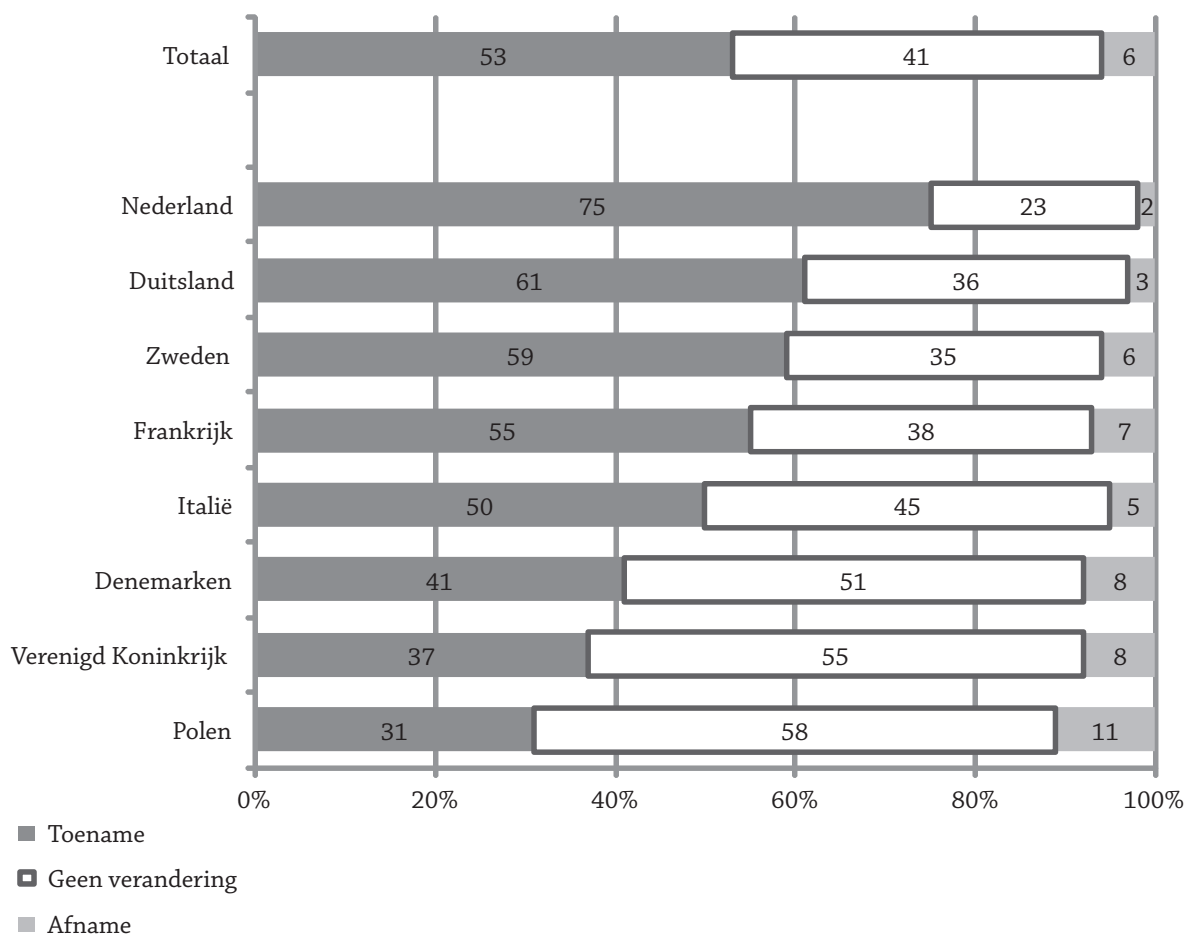

Figuur 3 Verwachtingen van werkgevers betreffende het arbeidskostenproductiviteitsgat bij een ouder wordend personeelsbestand, in procenten (bron: ASPA werkgeversonderzoek, 2009)

(53\%). De figuur laat grote verschillen zien tussen landen. Nederlandse werkgevers zijn het meest pessimistisch: $75 \%$ van de werkgevers verwacht dat het loonproductiviteitsgat zal toenemen als het personeelsbestand veroudert. In Polen en het Verenigd Koninkrijk is het loon-productiviteitsgat in mindere mate een issue; in deze landen denkt ongeveer een derde deel dat het loon-productiviteitsgat zal toenemen. Feitelijke loonprofielen in de desbetreffende landen zouden hierin een rol kunnen spelen: eerder onderzoek toont aan dat loonprofielen over het dienstverband in Nederland en Duitsland relatief steil zijn in vergelijking met die in andere landen (Deelen, 2012).

\section{Personeelsbeleid gericht op oudere werknemers}

Een relevante vraag is in hoeverre deze verwachtingen omtrent het loon-productiviteitsgat vertaald worden in het personeelsbeleid. Is het HRM-beleid gefocust op het in evenwicht brengen van kosten en baten van oudere werknemers? Om dergelijke vragen te kunnen beantwoorden hebben we werkgevers een lijst met maatregelen voorgelegd en gevraagd om aan te geven of hun organisatie deze maatregelen op dit moment toepast of overweegt toe te passen. Organisatiebeleid is ingedeeld in vier categorieën. De eerste categorie heeft als doel het bevorderen 
van productiviteit (opleidingsplan voor oudere werknemers); de tweede categorie kan opgevat worden als een manier om kosten te verlagen (vervroegd pensioen); de derde categorie focust zich op het in balans brengen van kosten en productiviteit (bijvoorbeeld door teruggang in zowel taken als salaris, ofwel demotie) en de vierde categorie bevat 'accommoderende maatregelen' (zoals extra verlofmogelijkheden en taakverlichting). Tabel 2 geeft een overzicht van het percentage werkgevers in de verschillende landen dat bepaalde maatregelen toepast en overweegt toe te passen.

In het algemeen passen werkgevers vooral flexibele werktijden toe als een maatregel om oudere werknemers te accommoderen (35\%). In verschillende landen, zoals Nederland en Denemarken, nemen organisaties verschillende maatregelen om behoeften van ouderen te accommoderen, bijvoorbeeld door middel van het aanbieden van extra verlofmogelijkheden voor oudere werknemers of taakverlichting. Naast de groep werkgevers die momenteel reeds accomoderende maatregelen toepast, is er een substantiële groep van werkgevers die overweegt om accommoderende maatregelen toe te gaan passen. In het algemeen overweegt circa een derde van de werkgevers de verschillende accommoderende maatregelen toe te gaan passen binnen de eigen organisatie.

Een leven lang leren wordt vaak gezien als de sleuteloplossing om de productiviteit op hogere leeftijd te verhogen (Europese Commissie, 2006; OECD, 2006). Het percentage organisaties dat opleidingsprogramma's voor ouder personeel aanbiedt, verschilt sterk tussen landen, maar is gemiddeld ongeveer een kwart. Relatief veel Britse werkgevers geven aan opleidingsplannen voor oudere werknemers te hebben (49\%). Ook Franse werkgevers passen relatief vaak opleidingsplannen toe. Dit zou kunnen voortkomen uit de intersectorale overeenkomst 'employee lifelong access to training; dit is een overeenkomst die in 2003 door de Franse sociale partners is getekend en die training onder ervaren werknemers promoot (OECD, 2006). Met name in landen waar momenteel relatief weinig werkgevers opleidingsprogramma's aanbieden, wordt opleiding door een grotere groep werkgevers overwogen.

Vervroegde uittredingsregelingen worden toegepast door $17 \%$ van de Europese werkgevers. In Nederland en Polen geeft ongeveer een derde deel van de werkgevers aan dergelijke regelingen aan te bieden. Ondanks de ontwikkelingen in de richting van langer doorwerken is er bovendien nog een groep van $33 \%$ van de Europese werkgevers die vervroegde uittredingsregelingen overweegt. In Polen, Frankrijk en Duitsland is dit percentage met meer dan $40 \%$ het hoogst.

Maatregelen die de productiviteit en beloning van oudere werknemers in balans brengen, zoals teruggang in functie én salaris (demotie), komen nagenoeg niet voor, met als uitzondering het Verenigd Koninkrijk, waar 22\% van de werkgevers deze maatregel toepast. De resultaten van tabel 2 laten zien dat in de meeste landen zowel opleidingsplannen als demotie - hoewel vaak voorgesteld door wetenschappers en beleidsmakers om negatieve consequenties van een verouderend personeelsbestand het hoofd te bieden - niet worden omarmd door werkgevers. Wél worden dergelijke maatregelen in verscheidene landen, zoals Duitsland, Nederland en Polen, door een relatief grote groep werkgevers overwogen. 


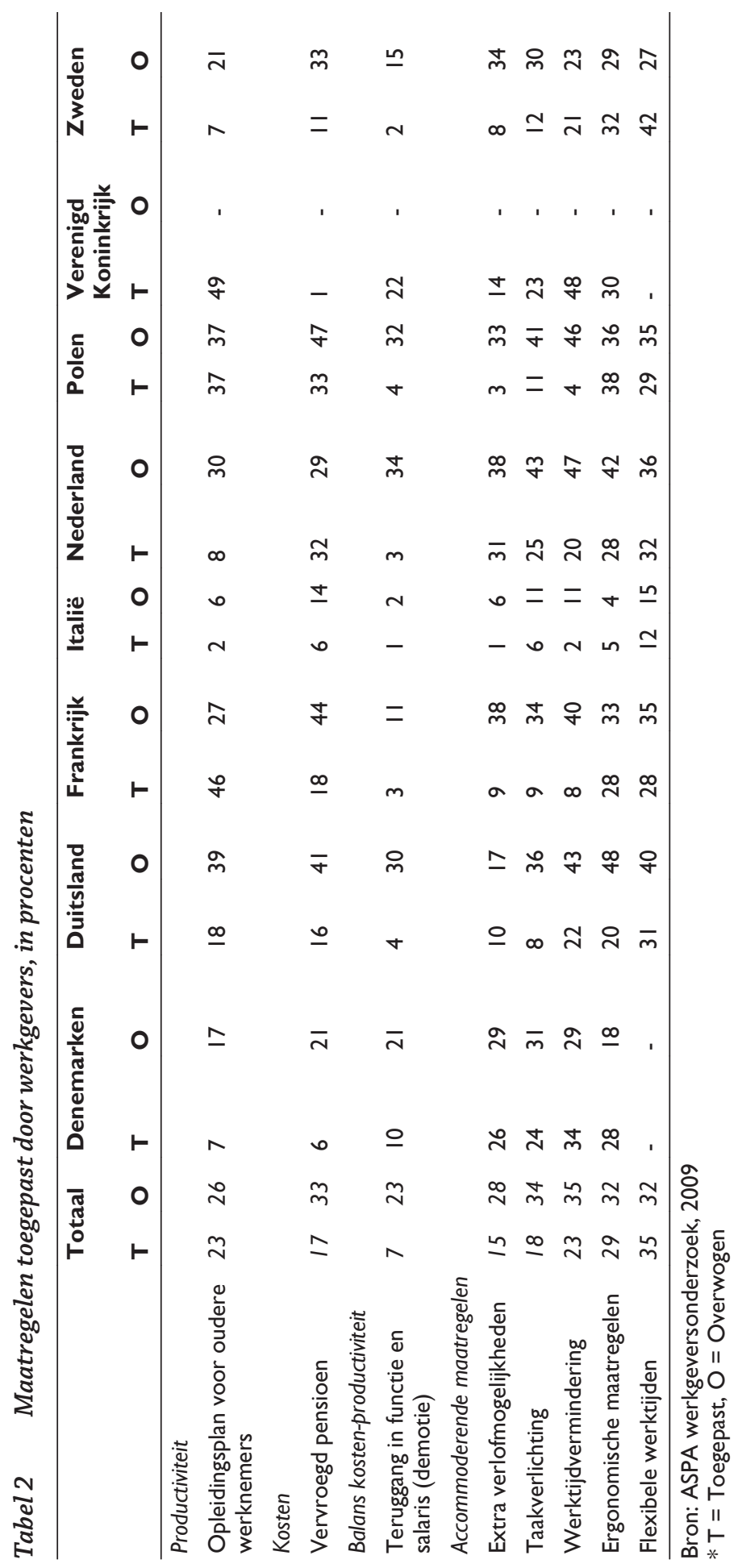




\section{Loon-productiviteitsgat en personeelsbeleid}

Tabel 3 geeft de resultaten weer van een multinomiale logistische regressie om beleid ten aanzien van oudere werknemers in meer detail te bekijken. De centrale vraag in deze analyse is: nemen werkgevers die een groter loon-productiviteitsgat verwachten vaker maatregelen om dit gat te dichten dan werkgevers die geen problemen verwachten met kosten en productiviteit? En in hoeverre overwegen werkgevers die een groter loon-productiviteitsgat verwachten vaker maatregelen om dit gat te dichten?

We hebben vier typen beleidsmaatregelen onderzocht: opleidingsplannen voor oudere werknemers (om arbeidsproductiviteit te verhogen); vervroegde uittredingsregelingen (om arbeidskosten te verlagen); teruggang in taken en salaris (demotie) (om balans (terug) te brengen tussen productiviteit en kosten); en taakverlichting (hetzelfde als 'demotie', maar dan zonder aanpassingen in de beloning). Deze vier afhankelijke variabelen hebben alle drie antwoordcategorieën: 1 = wordt toegepast, 2 = wordt/ zal worden overwogen en 3 = wordt niet toegepast en wordt/zal niet worden overwogen. In de multinomiale logistische regressie worden organisaties die bepaald beleid voeren (1) dan wel overwegen (2) vergeleken met organisaties die dit type beleid niet toepassen en ook niet overwegen (3).

We hebben getest of personeelsbeleid zoals gevoerd of overwogen door werkgevers samenhangt met het verwachte loon-productiviteitsgat. In het model hebben we de volgende structurele kenmerken van de organisatie opgenomen: het percentage oudere werknemers, de omvang van de organisatie, het niveau van werkzaamheden, de invloed van vakbonden, ervaren krapte bij werving en de verwachte groei van de organisatie. Daarnaast zijn controlevariabelen opgenomen met betrekking tot sector en landendummies. In tabel 3 zijn coëfficiënten weergegeven met tussen haakjes de bijbehorende z-waardes.

\section{Toegepast beleid}

Uit tabel 3 blijkt dat werkgevers die een groter gat verwachten, niet vaker de productiviteit proberen te verhogen via opleidingsplannen noch om balans te brengen in kosten en productiviteit door middel van demotie. Werkgevers die een groter loon-productiviteitsgat verwachten, passen echter wel vaker dan werkgevers die geen groot gat verwachten vervroegd pensioen toe, evenals accommoderende maatregelen zoals taakverlichting. Echter, als het gaat om taakverlichting kan er sprake zijn van een causaliteitsprobleem: misschien is het zo dat werkgevers die maatregelen toepassen om taken te verlichten, een groter gat verwachten.

Het toepassen van beleid gericht op oudere werknemers hangt positief samen met de omvang van de organisatie. Het zou zo kunnen zijn dat grotere organisaties meer mogelijkheden hebben om dergelijk beleid te implementeren en eerder van schaalvoordelen profiteren, zoals met de invoering van opleidingsplannen. Ook de invloed van vakbonden op personeelsbeleid hangt positief samen met het toepassen van beleid gericht op oudere werknemers. 


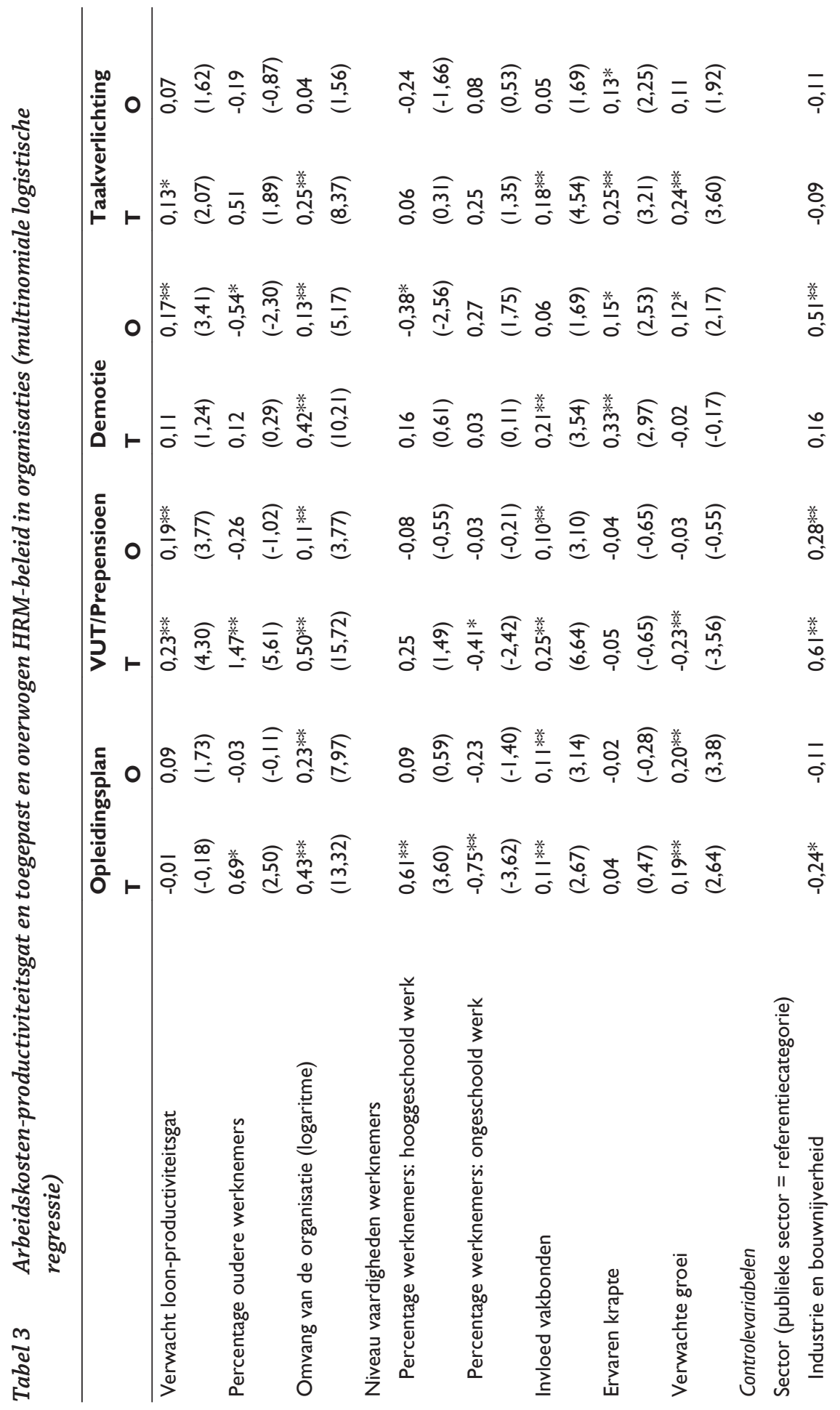




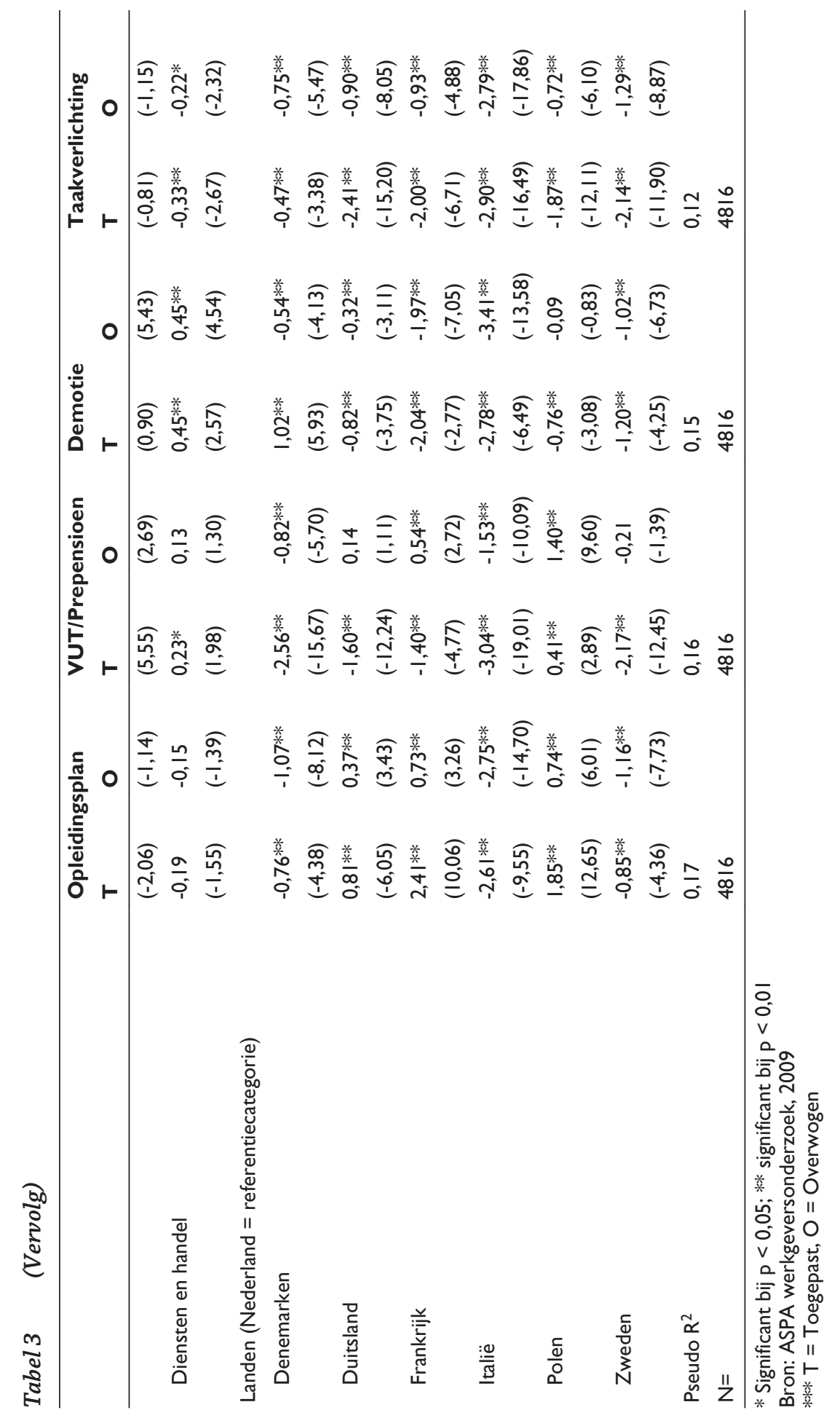


In organisaties waar een groter deel van het personeel hooggeschoold werk doet, worden opleidingsplannen vaker toegepast. In organisaties waar een groter deel van het personeel ongeschoold werk doet, worden minder vaak opleidingsplannen en regelingen voor vervroegd pensioen toegepast. Organisaties met een hoger percentage oudere werknemers hebben vaker regelingen voor vervroegd pensioen en opleidingsplannen. Dit laatste resultaat suggereert dat de veroudering van het personeelsbestand organisaties stimuleert om personeelsbeleid op dit gebied te ontwikkelen.

Ten slotte laten de resultaten duidelijke sectorverschillen zien. In de industrie- en bouwnijverheid passen werkgevers minder opleidingsplannen toe en meer regelingen voor vervroegde uittreding dan in de publieke sector. In de handel en dienstverlening wordt meer demotie en minder taakverlichting toegepast dan in de publieke sector.

\section{Overwogen beleid}

Uit tabel 3 komt verder naar voren dat werkgevers die een groter gat verwachten, wel vaker overwegen om demotie te zullen gaan toepassen. Ook vervroegd pensioen wordt door werkgevers die een groter loon-productiviteitsgat verwachten, vaker overwogen. Werkgevers die een groot gat verwachten, overwegen niet vaker opleidingsplannen noch accommoderende maatregelen zoals taakverlichting. Naast het toepassen van beleid gericht op oudere werknemers lijkt ook het overwegen van beleid positief samen te hangen met de omvang van de organisatie en de invloed van vakbonden op personeelsbeleid.

Met name met betrekking tot demotie komen nog een aantal andere opvallende resultaten naar voren. Zo wordt demotie minder vaak overwogen in organisaties met veel oudere werknemers en in organisaties waar een groter deel van het personeel hooggeschoold werk verricht. Daarentegen overwegen werkgevers die moeilijkheden ondervinden bij het werven van personeel en die groei verwachten, juist vaker demotie te zullen gaan toepassen. Ook zijn met betrekking tot het overwegen van demotie duidelijke sectorverschillen zichtbaar: in de industrie- en bouwnijverheid en diensten en handel overwegen werkgevers vaker demotie dan in de publieke sector.

\section{Conclusies en discussie}

In dit artikel hebben we ons gericht op twee hoofdvragen: Welke consequenties heeft een vergrijzend werknemersbestand volgens werkgevers in termen van arbeidskosten en productiviteit? En welke maatregelen nemen en overwegen werkgevers ten aanzien van hun oudere werknemers om arbeidskosten te verlagen, dan wel arbeidsproductiviteit te verhogen?

Uit de resultaten blijkt dat $75 \%$ van de Nederlandse werkgevers een toename in de arbeidskosten verwacht indien de gemiddelde leeftijd van het personeel met 5 jaar stijgt; dit is een aanmerkelijk hoger percentage dan in andere Europese landen (variërend tussen 16 en 51\%). De meerderheid van de Nederlandse werkgevers (58\%) verwacht dat de productiviteit gelijk zal blijven en circa een derde deel 
van de werkgevers verwacht een afname van de productiviteit. Verwachtingen omtrent productiviteit vertonen veel minder grote verschillen tussen landen dan verwachtingen omtrent arbeidskosten. De resultaten leggen belangrijke uitkomsten aan de dag als het gaat om verwachte veranderingen in kosten en opbrengsten bij een verouderend personeelsbestand, want een aanzienlijk deel van de Europese werkgevers voorziet een toenemend loon-productiviteitsgat als gevolg van de vergrijzing. Vooral in Nederland blijkt een aanzienlijk deel van de werkgevers een ouder wordend personeelsbestand te associëren met een groter wordend gat tussen arbeidskosten en productiviteit. Tot op heden lijkt het personeelsbeleid er nog niet op gericht om dit groter wordende gat te dichten. Hoewel demotie en een leven lang leren door wetenschappers en beleidsmakers vaak worden gezien als manieren om de kloof tussen arbeidskosten en productiviteit te verkleinen, wordt het enthousiasme voor deze maatregelen niet gedeeld door werkgevers. Behalve in het Verenigd Koninkrijk passen werkgevers nagenoeg geen demotie toe (om balans (terug) te brengen in productiviteit en kosten) en ook opleidingsplannen (om de productiviteit op peil te houden) worden door een minderheid van de werkgevers geïmplementeerd. Nederlandse werkgevers passen relatief vaak vervroegde pensionering van oudere werknemers toe, alsmede accommoderende maatregelen.

Men zou kunnen verwachten dat werkgevers die een groter gat tussen kosten en productiviteit verwachten er meer aan gelegen zijn om dit gat te dichten, en dat deze werkgevers dus vaker maatregelen zoals opleiding voor oudere werknemers en demotie toepassen. Dit blijkt echter niet het geval te zijn. Werkgevers die een groter gat tussen arbeidskosten en productiviteit verwachten, passen daarentegen wél vaker vervroegd pensioen toe of accommoderende maatregelen (zoals taakverlichting voor oudere werknemers). Met het oog op de toekomst lijken werkgevers die een groter gat tussen arbeidskosten en productiviteit verwachten, wel vaker demotie te overwegen.

Deze studie draagt op meerdere wijzen bij aan de bestaande literatuur. In de eerste plaats door niet zozeer onderzoek te doen naar feitelijke veranderingen in het loon-productiviteitsgat, maar door na te gaan wat de gepercipieerde consequenties van een vergrijzend personeelsbestand zijn in termen van arbeidskosten en productiviteit. Werkelijke ontwikkelingen in productiviteit en kosten in relatie tot ouder worden vormen belangrijke onderzoeksgebieden en zijn in wezen gericht op 'waarheidsvinding' rond de relatie tussen ouder worden, productiviteit en kosten. Verwachte ontwikkelingen lopen mogelijk niet altijd in de pas met feitelijke ontwikkelingen, maar geven daarentegen wel meer aanknopingspunten voor de vraag: hoe aannemelijk is het dat werkgevers bereid zijn om invulling te geven aan (werkbare) vormen van langer doorwerken? Bovendien is het niet onaannemelijk dat werkgevers - die voornamelijk geworven zijn binnen het hogere management - op basis van de aard van het werk en aan de hand van 'eerdere statistische ervaringen' (Phelps, 1972) een redelijk adequate inschatting kunnen maken van het algemene feitelijke verloop van de relatie tussen ouder worden, productiviteit en arbeidskosten.

Daarnaast is dit artikel een van de eerste die de verwachtingen van werkgevers vanuit een crossnationaal perspectief beziet. Deze crossnationale dimensie geeft 
meer informatie over de vraag in hoeverre percepties van Nederlandse werkgevers overeenkomen met dan wel verschillen van die van werkgevers in andere landen.

De studie kent daarentegen ook beperkingen. Een eerste beperking is gelegen in de hoogte en variatie in responspercentages in de verschillende landen. Zo kan een laag responspercentage bias in de steekproef veroorzaken als de non-respons ongelijk verdeeld is. Er is echter geen minimum als het gaat om een 'acceptabel' responspercentage: uit onderzoek blijkt dat in veel gevallen onderzoeken met verschillende responspercentages resultaten opleveren die statistisch niet van elkaar te onderscheiden zijn (Keeter et al., 2006). Ook een hoge respons staat evenwel niet garant voor representativiteit van de steekproef. Dit maakt het moeilijk om te bepalen in welke mate de nationale steekproeven representatief zijn voor de werkgeverspopulatie in het desbetreffende land.

Een andere beperking is gelegen in het feit dat de studie gebaseerd is op zelfgerapporteerd gedrag. Het is mogelijk dat respondenten aangeven dat ze bepaald beleid toepassen in overeenstemming met dominant personeelsbeleid of nationaal beleid, hoewel ze hier in werkelijkheid geen gevolg aan geven.

In dit onderzoek zagen we dat een belangrijke consequentie van een vergrijzend personeelsbestand volgens werkgevers is gelegen in een groter wordend gat tussen arbeidskosten en productiviteit; dit bleek met name een issue te zijn voor Nederlandse werkgevers. Om de verschillen tussen landen nader te duiden is een logische vervolgvraag in hoeverre en hoe zowel de institutionele context als organisatiekenmerken een rol spelen in de gepercipieerde toename van een arbeidskosten-productiviteitsgat. In Nederland blijken zowel het gepercipieerde niveau van ontslagbescherming als automatisch stijgende lonen belangrijke factoren te zijn in het verwachte gat tussen arbeidskosten en productiviteit (Conen et al., 2012a). Toekomstig onderzoek zou zich mogelijk kunnen focussen op andere factoren die een rol kunnen spelen, zoals de invloed van leeftijdgebonden secundaire arbeidsvoorwaarden, eerder gevoerd HR-beleid (bijvoorbeeld op het gebied van training en opleiding) en werkgeversbijdragen aan ziekte en arbeidsongeschiktheid.

Hiermee samenhangend is vanuit wetenschappelijk oogpunt een belangwekkende vervolgvraag in welke mate de gepercipieerde consequenties accuraat zijn, of dat werkgevers de ontwikkeling in arbeidskosten en productiviteit onder- dan wel overschatten. Toekomstig onderzoek zou percepties en feitelijke ontwikkelingen in arbeidskosten en productiviteit in organisaties kunnen trachten te combineren.

Voor beleidsmakers biedt het huidige onderzoek ook relevante aanknopingspunten. Aan de kostenkant spelen hoge arbeidskosten voor oudere werknemers een hoofdrol. Als antwoord hierop kan worden nagedacht over een vermindering van de loonstijging gedurende de carrière, een sterkere koppeling van beloning aan (een deel van) de prestaties, loonsubsidies en stimulansen voor werknemers om werk en pensioen te combineren. Men ziet loonsubsidies met name als een effectieve beleidsmaatregel om de arbeidsdeelname van oudere werknemers bij kleinere organisaties te verhogen; een overgrote meerderheid van de werkgevers beoordeelt stimulansen om werk en pensioen te combineren als effectief (Conen 
et al., 2012b). Aan de productiviteitskant kan worden nagedacht over manieren om fysieke en cognitieve productiviteit van ouderen gedurende de levensloop beter te waarborgen, zoals het stimuleren van technieken die lichaamsbelasting verminderen, gezondheidsprogramma's en (persoonsgebonden) trainingsbudgetten.

\section{Literatuur}

Aubert, P. \& Crépon, B. (2007). Are older workers less productive? Firm-level evidence on ageproductivity and age-wage profiles. Mimeo.

Baltes, P.B., Staudinger, U.M. \& Lindenberger, U. (1999). Lifespan Psychology: Theory and Application to Intellectual Functioning. Annual Review of Psychology, 50, 471-507.

Becker, G.S. (1962). Investment in human capital: A theoretical analysis. Journal of Political Economy, 70, 9-49.

Brewer, M.B., Dull, V. \& Lui, L. (1981). Perceptions of the elderly: Stereotypes as prototypes. Journal of Personality and Social Psychology, 41, 656-670.

Brewster, C., Hegewisch, A., Mayne, L. \& Tregaskis, O. (1994). Methodology of the Price Waterhouse Cranfield Project. In C. Brewster \& A. Hegewisch (Eds.), Policy and practice in European human resource management (pp. 230-245). London: Routledge.

Conen, W.S. (2013). Older workers: the view of Dutch employers in a European perspective. Amsterdam: Amsterdam University Press.

Conen, W.S., Dalen, H.P. \& Henkens, K. (2012a). Ageing and employers' perceptions of labour costs and productivity: a survey among European employers. International Journal of Manpower, 33, 629-647.

Conen, W.S., Henkens, K. \& Schippers, J.J. (2012b). Employers' attitudes and actions towards the extension of working lives in Europe. International Journal of Manpower, 33, 648-665.

Crépon, B., Deniau, N. \& Pérez-Duarte, S. (2002). Wages, productivity and worker characteristics: A French perspective. Mimeo, INSEE.

Dalen, H. van \& Henkens, K. (2014). De redelijkheid en waarschijnlijkheid van demotie. Economisch Statistische Berichten, 99, 708-711.

Deelen, A.P. (2012). Wage-tenure profiles and mobility. De Economist, 160, 141-155.

Devine, P.G. (1989). Stereotypes and prejudice: Their automatic and controlled components. Journal of Personality and Social Psychology, 56, 5-18.

Europese Commissie (2006). The demographic future of Europe - from challenge to opportunity. Brussels: Europese Commissie.

Eurostat (2015). Labour Force Survey Database.

Gelderblom, A. (2005). The relationship of age with productivity and wage. Rotterdam: SEOR.

Grossman, H. (1977). Risk Shifting and Reliability in Labor Markets. Scandinavian Journal of Economics, 79, 187-209.

Hall, D.T. \& Isabella, L.A. (1985). Downward movement and career development. Organizational Dynamics, 14, 5-23.

Harris, M. \& Holmstrom, B. (1982). A theory of Wage Dynamics. Review of Economic Studies, 49, 315-333.

Hellerstein, J.K. \& Neumark, D. (2004). Production function and wage equation estimation with heterogeneous labor: evidence from a new matched employer-employee data set. NBER Working Paper Series, 13, 345-371. 
Hidding, R., Jong, A. de, Krestin, M., Severijnen, T., Tromp, H., Vermeulen, M., Visman, L. \& Zuijdervliet, J. (2004). De oudere werknemer. Omgaan met vergrijzing in de organisatie. Hoofddorp: STECR.

Hilton, J.L. \& Hippel, W. von (1996). Stereotypes. Annual Review of Psychology, 47, 237-271.

Horn, J.L. \& Catell, R.B. (1967). Age differences in fluid and crystallized intelligence. Acta Psychologica, 26, 107-129.

Hutchens, R.M. (1989). Seniority, wages and productivity: A turbulent decade. Journal of Economic Perspectives, 3, 49-64.

Ilmakunnas, P. \& Maliranta, M. (2005). Technology, worker characteristics, and wage-productivity gaps. Oxford Bulletin of Economics and Statistics, 67, 623-645.

Kalleberg, A.L., Knoke, D., Marsden, P. \& Spaeth, J. (1996). Organizations in America: Analyzing their structures and Human Resource Practices. London: Sage Publications.

Keeter, S., Kennedy, C., Dimock, M., Best, J. \& Craighill, P. (2006). Gauging the Impact of Growing Nonresponse on Estimates from a National RDD Telephone Survey. Public Opinion Quarterly, 70, 759-779.

Kotlikoff, L.J. \& Gokhale, J. (1992). Estimating a firm's age-productivity profile using the present value of workers' earning. The Quarterly Journal of Economics, 4, 1215-1242.

Lalonde, R.N. \& Gardner, R.C. (1989). An intergroup perspective on stereotype organization and processing. British Journal of Social Psychology, 28, 289-303.

Lazear, E.P. (1979). Why is there mandatory retirement? Journal of Political Economy, 87, 1261-1274.

Lee, J.A. \& T. Clemons (1985). Factors affecting employment decisions about older workers. Journal of Applied Psychology, 70, 785-788.

Linville, P.W., Fischer, G.W. \& Salovey, P. (1989). Perceived distributions of the characteristics of in-group and out-group members: empirical evidence and a computer simulation. Journal of Personality and Social Psychology, 57, 165-188.

Macrae, C.N. \& Bodenhausen, G.V. (2001). Social cognition: categorical person perception. British Journal of Psychology, 92, 239-255.

Nauta, A., Bruin, M.R. de \& Cremer, R. (2004). De mythe doorbroken. Gezondheid en inzetbaarheid oudere werknemers. Hoofddorp: TNO Arbeid.

OECD (2006). Live longer, work longer. Paris: OECD Publishing.

OECD (2015). Ageing and Employment Policies: Statistics on average effective age of retirement, geraadpleegd op 8 januari 2015 van www.oecd.org/insurance/ pensionsystems/ageingandemploymentpolicies-statisticsonaverageeffectiveageof retirement.htm.

Ours, J.C. van \& Stoeldraijer, L. (2010). Age, wage and productivity in Dutch manufacturing. De Economist, 159, 113-137.

Phelps, E.S. (1972). The statistical theory of racism and sexism. The American Economic Review, 62, 659-661.

Polachek, S.W. \& Siebert, W.S. (1993). The economics of earnings. Cambridge, MA: Cambridge University Press.

Remery, C., Henkens, K., Schippers, J.J. \& Ekamper, P. (2003). Managing an ageing workforce and a tight labor market: Views held by Dutch employers. Population Research and Policy Review, 22, 21-40.

Skirbekk, V. (2008). Age and productivity potential: A new approach based on ability levels and industry-wide task demand. Population and Development Review, 34, 191-207.

Snyder, M. (1981). On the self-perpetuating nature of social stereotypes. In D.L. Hamilton (Ed.), Cognitive processes in stereotyping and intergroup behavior (pp. 183-212). Hillsdale, NJ: Lawrence Erlbaum. 
SZW (1991). Ouderenbeleid in arbeidsorganisaties. Den Haag: Ministerie van Sociale Zaken en Werkgelegenheid.

Tajfel, H. \& Turner, J.C. (1979). An integrative theory of intergroup conflict. In W.G. Austin \& S. Worchel (Eds.), The social psychology of intergroup relations (pp. 33-47). Montery, CA: Brooks-Cole.

Verkuyten, M. \& Nekuee, S. (1999). Ingroup-bias: the effect of self-stereotyping, identification and group threat. European Journal of Social Psychology, 29, 411-418.

Vickerstaff, S., Cox, J. \& Keen, L. (2003). Employers and the management of retirement. Social Policy \& Administration, 37, 271-287.

\section{Bijlage 1}

\begin{tabular}{llll}
\hline Land & $\mathbf{N}$ & Respons & Methode \\
\hline Denemarken & 609 & $28 \%$ & CAWI \\
Duitsland & 892 & $11 \%$ & PAPI \\
Frankrijk & 500 & $7 \%$ & CATI \\
Italië & 770 & $17 \%$ & CATI \\
Nederland & 1077 & $23 \%$ & PAPI \\
Polen & 1037 & $53 \%$ & CATI \\
Verenigd Koninkrijk & 412 & $22 \%$ & CATI \\
Zweden & 525 & $22 \%$ & PAPI \\
\hline
\end{tabular}

